\title{
FIRES DUE TO SELFIGNITION IN (MSWS) MUNICIPAL SOLID WASTE STORAGES
}

\author{
M. A. Ibrahim* \\ W. Hogland* \\ E. Elmberg* \\ A. Lönnermark** \\ H. Person** \\ * School of Natural Sciences, Linnaeus University Kalmar, Sweden \\ ** SP: Swedish National Testing and Research Institute, Sweden
}

\begin{abstract}
Growing energy demands and global emphasis on employing sustainable energy resources to meet energy requirements result in increased importance of MSW (municipal solid waste) as a valuable carbondioxide neutral fuel. There is a need to study the factors that may lead to selfignition of MSW, if stored for sufficiently longer period of time. A better understanding of these factors may help in establishing the practicle guidelines for efficient handling of MSW and to reduce the environmental and social costs caused by selfigniting fires. Its importance is evident from the fact that millions of euros are lost every year in Sweden because of spontaneous fires. These fires cause loss of valuable material and injuries to people, and they are also associated with intense environmental pollution, in particular in the form of smoke and water pollution. This study is based on a questionnaire survey among the members of the Swedish waste management association (Avfall Sverige), whose members service $95 \%$ of the Swedish population. The response to the survey was $60 \%$. A total of 96 major surface fires have been reported in the past 10 years at storage sites. $74 \%$ of these 96 fire incidents were due to self-ignition, $11 \%$ were due to known causes other than self-ignition and $15 \%$ were due to unknown reasons. In reference to the type of storage, $50 \%$ of these 96 fire incidents took place at sites that store both household and industrial waste, $20 \%$ at sites that store only industrial waste, and $30 \%$ at sites that store household, industrial, and agricultural waste. Regarding the most frequent cause of fire at any storage site, $33 \%$ of respondents relate the fire incidents with extreme hot weather conditions, $8 \%$ of respondents report that fire incidents at their storage site are mostly an aftereffect of rainfall, $13 \%$ relate the fire incidents with cold weather in December, and $46 \%$ of respondents experienced the fire incidents throughout the whole year.

Based on data covering the last 10 years, the average annual amount of emissions of dioxins is (upper/lower bound) TCDD 0.03/0.12 g, PAH 0.98/3.7 tons, PCB 1.66/6.31 g, $\mathrm{Hg}$ $16.51 / 62.59 \mathrm{~g}$, and VOC 18/68 tons from MSW storage fires in Sweden.
\end{abstract}

\section{KEYWORDS}

Municipal solid waste (MSW); Organic material; Self-ignition; Fires in storage sites; Emissions. 


\section{INTRODUCTION}

The current era utilizes organic recyclables as a fuel and storage of organic materials. EU Council Directive 1999/31/EC of April 1999 as well as 2008/98/EC of November 2008 regarding land filling paved the way for building this conception. Its accomplishment is evident from the exponential growth in the number of incinerators, recycling units, and compostors, and the diminishing active landfill sites in European countries during the first decade of this millennium. One excellent paradigm shift is in Sweden, where only one incineration plant existed in 1960, and 14 in 1980, increasing to 21 during the 1980 s, after which the number was stable up to the beginning of the new millennium and has now increased to 31 in 2010. Because of the mentioned Directive and the declining number of active landfill sites, most municipal solid waste (MSW) is directed toward incineration plants, composting plants, recycling units, and biogas plants. From 1994 to 2008, there was a drop of $72.5 \%$ in the amount of waste that was landfilled in Sweden [1].

MSW in Sweden is processed as fuel for incineration plants and as feed to recycling and composting plants. The amount of MSW that was composted, biologically treated, incinerated, and dumped into landfills in Sweden in the year 2008 was 0.56, 0.97, 4.56, and 1.67 million tons, respectively [1]. Storage of MSW for incineration, recycling, and composting varies seasonally, and it could include baling (cylindrical bales and rectangular bales, which can be wrapped with low-density polyethylene (LDPE) or be unwrapped), loose storage, and hard compacted storage. At a hard compact storage site, MSW is distributed in layers of 30-50 cm. A compactor rolls over each layer and compacts it before putting the next layer of MSW on top of it. At a loose compact storage site, MSW is dumped randomly. Meanwhile, at baled storage sites, MSW may be formed into the shape of a bale (either cylindrical or rectangular) and may or may not be covered by a plastic sheet.

During the storage period, there is a risk of fire, commonly referred to as self-ignition, as a result of biological and chemical decomposition [2, 3, 4]. Other causes of an undesirable fire could be sparks during high-speed grinding of waste, dust explosions in bunker/pit environments, sparks caused by clamshell friction, and waste may also contain spontaneously ignitable materials like batteries, metals, etc. Another cause could be mixing of smoldering waste (e.g., disposal of barbecues) with ordinary waste.

These undesirable fires in the storage of organic fuels not only cause loss of useful materials that are burned $[5,6,7]$ and environmental pollution, particularly in the form of smoke and water pollution $[7,8,9,10,11,12]$, but also might be associated with personal injuries and fatalities [4].

The storage of waste and the risk of fires, as well as other hazards, have not been fully investigated in Sweden; hence, there is a need to collect statistics to evaluate the risks associated with fires in such storage sites [4]. However, self-ignition in bale storage sites has so far not been reported [13, 14].

In previous studies, different causes of fires in MSW storages were assumed-e.g., arson for 1989-1990 - and in 2002, auto-ignition was assumed as the main cause of fire [6, 15]. This study attempts to analyze and provide statistics regarding fires at waste fuel storage sites and to take one step toward a better understanding of the issues regarding incidents of fires at modern storage sites for organic fuels in Sweden. Because the regulations have changed, it is of great interest to study how modern ways of storing waste affect the risk of fires starting and spreading. 


\section{METHOD}

This study is based on electronic data collection using a questionnaire survey. Questionnaire surveys may be classified into three categories: open-ended, close-ended, and partially closeended questionnaires [16]. Furthermore, three major techniques are available for collecting data electronically; namely, computer-administered survey, electronic mail survey, and web survey [17]. In this study, a close-ended questionnaire using the web-survey technique was employed for the electronic collection of data. This choice was made because open-ended questions have a high nonresponse rate and are difficult to subject to statistical analysis [18]. Furthermore, it is known that statistical interpretation of answers to close-ended questionnaires is much easier. The web-survey technique is becoming more and more popular because of the ease of organization and implementation of such surveys [17]. A computeradministered survey was employed rather than a paper-based survey because both modes of data collection give comparable results, and it is more effective to collect the data from higher management, because of direct access to the Internet [19]. Furthermore, internet-based surveys are comparatively cheap, feedback is received more efficiently, and they are easy to build and have wider geographical reach [19]. Although there is a lower, but still nonzero, probability of inappropriate responses with web-based surveys [19, 20, 21], telephone interviews were also made afterwards to obtain further elaboration of answers from respondents.

Initially, a contact list of environmental managers of municipalities, incineration plants, biogas plants, composting plants, and landfills in Sweden was established. Afterwards, a questionnaire was sent to a total of 110 environmental managers in 44 municipalities and 66 companies across the whole of Sweden. An incentive was offered to respondents regarding sharing of the results of this study as it may be beneficial to provide some incentive to the potential respondents of a survey [22].

Out of these 44 municipalities, 11 have a population of less than 10,000, 12 have between 10,000 and 20,000, 11 have between 20,000 and 30,000, and 10 municipalities have between 30,000 and 0.2 million. All of these companies and municipalities are members of Avfall Sverige (Swedish Waste Management Association), whose members service 95\% of the Swedish population.

A reminder was sent to environmental managers in all companies/municipalities who did not respond to the first questionnaire that was sent out. The initial phase gave first-hand information about the critical issues. In the second round, some more detailed information was gathered by a second questionnaire, and in the third round, a representative of these company/municipality managers was interviewed by telephone, Skype, email, or directly in personal meetings.

\section{$1.1 \quad$ 2.1. Statistics}

Statistics were collected regarding major undesirable fire incidents in the storage of organic recyclables and waste fuels for the last 10 years from 2000 to 2010. Statistics regarding only surface fires were collected because deep-seated fires are associated with lower emissions as a result of condensation of heavier species on their way to the surface [15]. However, deepseated fires can lead to high emissions if allowed to burn for a long time. Deep seated fires can be difficult to extinguish.

The statistics were collected from all types of stakeholders that are involved in the handling of organic recyclables and waste fuels during their life-cycle period. This may include 
municipalities and/or companies that are involved in collection, transportation, storage, and processing of MSW.

\section{RESULTS AND DISCUSSION}

The overall response to the survey was $60 \%$, responses from municipalities and companies being $46 \%$ and $62 \%$, respectively. The individual responses of the four subcategories of municipalities was $28 \%$ for those that have a population of less than $10,000,59 \%$ for those that have a population between 10,000 and $20,000,55 \%$ for those that have a population between 20,000 to 30,000 , and $40 \%$ for municipalities that have a population between 30,000 and 0.2 million.

\subsection{Fire statistics}

A total of 96 major surface fire incidents are reported in Table 1 for the 10-year period, in which a significant amount of material was burned, causing significant economic losses that are worth reporting. Respondents to the survey specified a range of material burned and an amount of economic loss in major fires. Both upper and lower limits are reported here for losses as well as for the amount of material burned. For the sake of better estimation of the amount of emissions, for the storage sites where amount of individual type of material burned is not sure, the total amount of waste material burned is equally distributed among types of wastes stored at that storage site. In terms of losses, 2009 seems to be the worst year, costing 10.8 million Swedish kronor (SEK) or about 1 million euros. 2006 seems to be the worst year in terms of the highest amount of material burned. It is seen that almost all fires broke out in loose compact storage sites except for one fire that was reported in a hard compact storage site.

Table 2 provides information regarding various causes of fires in relation to the type of storage. The storage sites are classified into five types of storage depending on the combination of waste stored in them. Out of these 96 fire incidents, 71 fires were due to selfignition, 11 had causes other than self-ignition, and 14 had unknown causes. 
Table 1. Fire incidents and amount of different types of MSW accidentally burned in the past 10 years (lower/upper bound)

\begin{tabular}{|c|c|c|c|c|c|c|}
\hline Year & $\begin{array}{l}\text { Number } \\
\text { of Fires }\end{array}$ & $\begin{array}{l}\text { Material Burned } \\
\quad \text { (tons) }\end{array}$ & 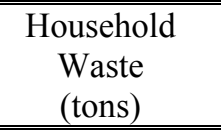 & $\begin{array}{c}\text { Agricultural } \\
\text { Waste } \\
\text { (tons) } \\
\end{array}$ & $\begin{array}{l}\text { Industrial Waste } \\
\text { (tons) }\end{array}$ & $\begin{array}{l}\text { Losses } \\
\text { (M SEK) }\end{array}$ \\
\hline 2000 & 5 & $2,000 / 7,000$ & $500 / 1,000$ & - & $1,500 / 6,000$ & $0.01 / 0.1$ \\
\hline 2001 & 6 & $1,600 / 3,000$ & $700 / 1,350$ & $200 / 300$ & $700 / 1,350$ & $0.10 / 0.5$ \\
\hline 2002 & 9 & $3,600 / 9,000$ & $1,200 / 1,850$ & $200 / 300$ & $2,200 / 6,850$ & $1.00 / 10.1$ \\
\hline 2003 & 6 & $6,500 / 24,000$ & $2,500 / 8,700$ & $1,500 / 6,650$ & $2,500 / 8,650$ & $0.12 / 0.7$ \\
\hline 2004 & 4 & $6,600 / 27,000$ & $1,950 / 7,500$ & $1,700 / 7,000$ & $2,950 / 12,500$ & $0.1 / 0.5$ \\
\hline 2005 & 8 & $8,400 / 29,000$ & $2,700 / 10,500$ & $2,000 / 7,000$ & $3,700 / 11,500$ & $0.12 / 0.7$ \\
\hline 2006 & 15 & $11,100 / 39,000$ & $3,450 / 12,000$ & $1,700 / 7,000$ & $5,950 / 20,000$ & $0.66 / 2.1$ \\
\hline 2007 & 12 & $9,000 / 36,000$ & $3,550 / 14,000$ & $1,700 / 7,000$ & $3,750 / 15,000$ & $1.71 / 4.1$ \\
\hline 2008 & 15 & $7,150 / 31,000$ & $2,400 / 9,500$ & $400 / 2,000$ & $4,350 / 19,500$ & $1.63 / 3.8$ \\
\hline 2009 & 13 & $3,800 / 21,000$ & $1,400 / 6,000$ & $400 / 2,000$ & $2,000 / 13,000$ & $1.13 / 10.8$ \\
\hline $\begin{array}{l}\text { Up to } \\
\text { May } \\
2010\end{array}$ & 3 & $2,000 / 4,000$ & $750 / 1,500$ & - & $1,250 / 2,500$ & $0.03 / 0.3$ \\
\hline Total & 96 & $61,800 / 230,000$ & $21,100 / 73,900$ & $9,850 / 39,250$ & $30,850 / 116,850$ & $6.61 / 33.6$ \\
\hline $\begin{array}{c}\text { Average } \\
\text { (based } \\
\text { on } 10 \\
\text { years) }\end{array}$ & 9.6 & $6,180 / 23,000$ & $2,110 / 7,390$ & $985 / 3,925$ & $3,085 / 11,685$ & $0.66 / 3.36$ \\
\hline
\end{tabular}

Table 2. Number of fires vs type of storage

\begin{tabular}{cccc|r}
\hline \hline Type of storage & Self-ignition & Other sources & Unknown & Total \\
\hline \hline Household & - & - & 2 & 2 \\
Industrial & 14 & 8 & - & 22 \\
Household and Industrial & 36 & 3 & 12 & 51 \\
Household, Agricultural, and Industrial & 21 & - & - & 21 \\
\hline Total & 71 & 11 & 14 & 96 \\
\hline \hline
\end{tabular}

Respondents were also asked about any relationship between incidents of fires and any particular period in the year. Forty-six percent of respondents experience fire incidents throughout the year, 33\% of respondents relate fire incidents with extremely hot weather (June to August), $8 \%$ of respondents report that fire incidents at their storage site are mostly an aftereffect of rainfall, and $13 \%$ relate it to winter weather conditions (December). The last $13 \%$ give support to the school of thought of those who believe that during winter, MSW get covered with ice, and biological activity inside the storage dump increases the temperature and eventually causes some undesirable fire incidents. However, no evidence has been found in the literature to confirm this hypothesis. 


\subsection{Emissions}

Pollutant emissions were calculated by summing up the individual effects of different types of material burned in each fire. The calculation of pollutant emissions using any base year may not be a good representative of the average amount of emissions for a particular year, as there are not uniform numbers of fires in each year. Furthermore, a single large incident may contribute significantly to the total annual emissions in the country $[5,7]$. Therefore, data for the last 10 years were collected to understand better the new storage trends and their relation with the fire incidents. Furthermore, this gives a better estimate of average annual emission inventory in Sweden resulting from fires in MSW storage sites. Currently, there are very few data available for making a comparison of new trends in dioxin emission inventories in Sweden. Table 3 provides a comparison of this study and the only recent organized study available regarding emission inventories resulting from fires in Sweden, by Blomqvist. The study by Blomqvist is based on the statistics of a single year, 1999. Furthermore, the estimates made by Blomqvist in Table 3 regarding emissions from fires in MSW storage sites are not based on real fire statistics but on fire load data given in [23] regarding investigation of risk objects, and therefore cannot help in providing a reliable comparison of results with this study However, emission estimates made by Blomqvist regarding fires in buildings, vehicles, garbage containers, and forests are based on real statistics, and a comparison in Table 3 shows that emission inventories of dioxins, PAHs, and VOCs estimated in this study lie closer to the lower limit of emission values estimated by Blomqvist and that emissions from fires in organic storage sites are a fraction of emissions from fires in buildings, vehicles, garbage containers, and forests. In this study dioxin emissions are reported in terms of TEQ and are currently most reliable method for assessing the potential toxicity of complex mixtures [24] and units used are same as in literature sources because due to lack of details of individual congeners, TCDD equivalent found in literature cannot be converted to common basis reagarding toxicity equivalent factors (TEF's) [7].

\subsubsection{Uncertainties}

This section discusses the various studies conducted regarding dioxin emission inventories in Europe, and Sweden in particular. The dioxin emissions due to uncontrolled fires in Sweden lies between 2.8 and 30 (g-N-TEQ/a) for both 1990 and 1993; however, there is a decreasing trend in total dioxin emissions from 1990 to 1993 [25, 26]. There is a maximum of $84 \%$ and a minimum of $4 \%$ decrease in the emission inventories of dioxins in Europe because of fires for the years 1983 to 2005 [27]. While considering these figures, uncertainties associated with them should be kept in mind. Emission inventories for Sweden reported by UNEP have inherent uncertainties because the data are based on personal communications and not on any reports [26]. European dioxin emission inventories are calculated based on unrefined and limited data, and so they have limited quality [28].

There is an inherent uncertainty regarding defining the emission factors because of nonreproducible results of emission calculations [7]. Another reason for uncertainty is that many reports on emissions of dioxins and PAHs are based on stubble burning, and only a limited number of compounds are measured in those studies [30]. 
Linnaeus ECO-TECH '10

Kalmar, Sweden, November 22-24, 2010

Table 3. Estimation of total emissions (lower/upper bound) from fires in Sweden averaged over the last 10 years and comparison with other studies

\begin{tabular}{|c|c|c|c|c|c|c|c|}
\hline & & \multicolumn{5}{|c|}{ Emissions } & \\
\hline & & $\begin{array}{l}\text { Chlorobe } \\
\text { nzene }\end{array}$ & Dioxins & $\begin{array}{l}\text { PAH } \\
\text { (ton) }\end{array}$ & $\begin{array}{c}\text { PCB } \\
(\mathrm{g})\end{array}$ & $\begin{array}{l}\mathrm{Hg} \\
(\mathrm{g})\end{array}$ & $\begin{array}{l}\text { VOC } \\
\text { (ton) }\end{array}$ \\
\hline$\stackrel{n}{\vec{E}} \frac{D}{E}$ & $\begin{array}{c}\text { Fires in } \\
\text { MSW } \\
\text { storages on } \\
\text { average for } \\
\text { the last } 10 \\
\text { years }\end{array}$ & $\begin{array}{c}71.59 / 271 \\
.47\end{array}$ & $\begin{array}{c}0.03 / 0.12 \\
\text { (TCDD) (g } \\
\text { TEQ) }\end{array}$ & $0.98 / 3.7$ & $1.66 / 6.31$ & $16.51 / 62.59$ & $18 / 68$ \\
\hline 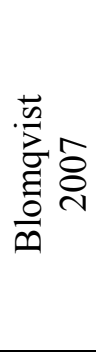 & $\begin{array}{c}\text { Fires in } \\
\text { MSW } \\
\text { storages } \\
\text { (estimate } \\
\text { based on } \\
\text { potential } \\
\text { fires for } \\
\text { year 1999) }\end{array}$ & - & $\begin{array}{c}0.1 / 2.3 \\
(\mathrm{PCDD} / \mathrm{F})(\mathrm{g} \\
\text { TEQ) }\end{array}$ & $0.003 / 0.065$ & - & - & - \\
\hline 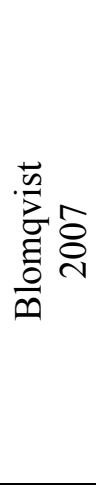 & $\begin{array}{c}\text { Total } \\
\text { number of } \\
\text { fires in } \\
\text { buildings, } \\
\text { vehicles, } \\
\text { municipal } \\
\text { containers, } \\
\text { and forest } \\
\text { in } 1999 \\
\text { (based on } \\
\text { statistics) }\end{array}$ & - & $\begin{array}{c}0.5 / 1.4 \\
(\mathrm{PCDD} / \mathrm{F})(\mathrm{g} \\
\mathrm{TEQ})\end{array}$ & $2 / 12$ & - & - & $13 / 200$ \\
\hline 穵 & $\begin{array}{c}\text { Fires in } \\
\text { MSW } \\
\text { storages } \\
\text { (base year } \\
\text { 1993) }\end{array}$ & - & $\begin{array}{c}2.8 / 30 \\
(\mathrm{PCDD} / \mathrm{F})(\mathrm{g} \\
\text { TEQ) }\end{array}$ & & - & - & - \\
\hline
\end{tabular}


Table 4. Formation of potential contaminants [29]

\begin{tabular}{|c|c|c|c|c|c|c|}
\hline & \multicolumn{6}{|c|}{ Formation of contaminants per kg of landfilled dry organic material } \\
\hline & $\begin{array}{c}\text { Ordinary } \\
\text { domestic } \\
\text { waste } \\
(\mathrm{kg} / \mathrm{kg}) \\
\end{array}$ & $\begin{array}{l}\text { Bulky } \\
\text { domestic } \\
\text { waste } \\
(\mathrm{kg} / \mathrm{kg}) \\
\end{array}$ & $\begin{array}{l}\text { Industrial } \\
\text { waste } \\
(\mathrm{kg} / \mathrm{kg}) \\
\end{array}$ & $\begin{array}{l}\text { Construction } \\
\text { and } \\
\text { demolition } \\
\text { wastes } \\
(\mathrm{kg} / \mathrm{kg}) \\
\end{array}$ & $\begin{array}{c}\text { Other } \\
\text { wastes } \\
(\mathrm{kg} / \mathrm{kg})\end{array}$ & $\begin{array}{l}\text { Average } \\
(\mathrm{kg} / \mathrm{kg}) \\
\end{array}$ \\
\hline Chlorobenzene & $4 \cdot 10^{-9}$ & $8 \cdot 10^{-8}$ & $1.6 \cdot 10^{-8}$ & $1.2 \cdot 10^{-8}$ & $\begin{array}{c}1.0^{\circ} \\
10^{-9}\end{array}$ & $\frac{1.4}{8} \cdot 10^{-}$ \\
\hline $\begin{array}{l}\text { Dioxins } \\
\text { (TCDD eq) }\end{array}$ & $1.8 \cdot 10^{-12}$ & $3.6 \cdot 10^{-11}$ & $7.3 \cdot 10^{-}$ & $5.5 \cdot 10^{-12}$ & $\begin{array}{l}4.5^{-11} \\
10^{-11}\end{array}$ & $\begin{array}{l}6.4 \cdot 10^{-} \\
12\end{array}$ \\
\hline PAH & $5.4 \cdot 10^{-8}$ & $1 \cdot 10^{-6}$ & $2.2 \cdot 10^{-7}$ & $1.6 \cdot 10^{-7}$ & $\begin{array}{c}1.4^{\circ} \\
10^{-6}\end{array}$ & $1.9 \cdot 10^{-}$ \\
\hline PCB & $9.3 \cdot 10^{-11}$ & $1.8 \cdot 10^{-9}$ & $\underset{10}{3.7} \cdot 10^{-}$ & $2.8 \cdot 10^{-10}$ & $\begin{array}{c}2.33 \\
10^{-9}\end{array}$ & $\begin{array}{l}3.3 \cdot 10^{-} \\
10\end{array}$ \\
\hline $\mathrm{Hg}$ & $9.2 \cdot 10^{-10}$ & $1.8 \cdot 10^{-8}$ & $3.7 \cdot 10^{-9}$ & $2.75 \cdot 10^{-9}$ & $\begin{array}{c}2.3^{\circ} \\
10^{-8} \\
\end{array}$ & $\frac{3.2}{9} \cdot 10^{-}$ \\
\hline
\end{tabular}

Other causes of uncertainty could arise from estimating the total amount and types of material burned in each fire, and from the fire statistics themselves. Therefore, emissions are reported as upper and lower bounds to accommodate the possible uncertainty in the data.

Furthermore, the upper and lower bounds of dioxin emissions calculated in this study have lower values compared to emissions inventories reported in the literature for 1990 and 1993. This may reflect repercussions of the implementation of EU directives.

\subsubsection{Emission factors}

Emission factors used for emission calculation are reported in Table 4. For agricultural waste, an average value of emission factors is considered, as mentioned in Table 4. Emission factors reported in Table 4 are calculated based on the studies conducted by [10, 31, 29].

The emission factor for VOC is $2 \mathrm{~kg} /$ ton of agricultural waste burned $[8,9,30]$, and the same is used for industrial waste. The emission factor for VOC for household waste is $5 \mathrm{~kg} /$ ton of waste burned [11].

\section{CONCLUSIONS}

Average yearly emission inventories of dioxins, PAH, PCB, VOC, and $\mathrm{Hg}$ were calculated based on the estimated amounts of different types of MSW burned in individual fires in the past 10 years. The reason of having very little information in the literature for making comparison of results regarding emission inventories in Europe, and Sweden in particular, is due to lack of comprehensive real statistics regarding fire incidents in MSW storage sites. This study takes one step in the direction of providing this missing information.

There are inherent uncertainties associated with the estimation of emissions, which are accommodated by presenting the data in the form of upper and lower bounds. A part of this 
uncertainty can be overcome if more detailed information concerning real emissions is available [5].

The following conclusions are drawn.

- Close-ended web-based surveys are proved to be a more reliable technique for collecting data from environmental managers.

- Fire statistics showed that loose compact storage is the most vulnerable storage technique with regard to catching fire, and almost all fires are reported in loose compact storage sites, except for one that was in a hard compact storage site (Table 2). This is further supported by the landfill fire statistics collected in Finland, which conclude that insufficient compacting is more often the major cause of landfill fires [32].

- The maximum number of fire incidents, i.e., $50 \%$, took place in loose compact storage sites that stored both household and industrial waste .

- Some of the respondents report the use of manual monitoring of the storage area. Shifting toward automation may help to improve the safety situation. Automatic laserbased sensors can be employed for the screening of incoming dumpers as well as at storage sites.

- Regarding the most frequent cause of fire at any storage site, $33 \%$ of respondents relate the fire incidents with extreme hot weather conditions, and $8 \%$ of respondents report that fire incidents at their storage site are mostly an aftereffect of rainfall. It may be concluded that environmental managers should be more cautious during summer, because most of the fires broke out during this period. Furthermore, wrapping and compaction of MSW during storage may further reduce the number of fire incidents.

- In this study, no fire incident was reported in baled storage sites (either cylindrical or rectangular), which is why a shift from loose compact storage toward baling may reduce the risk of fires $[13,14]$.

A more comprehensive estimate regarding the environmental impact of accidental fires in waste storage sites can be obtained by considering the impact of fires on water and soil as well as that on air [7].

The collection of fire statistics in this study may not help comprehensively in fire prevention but merely highlights one aspect regarding the most vulnerable type of storage, type of MSW, and weather conditions for MSW to catch fire. An effective collaboration with local environmental authorities, fire brigades, and more detailed statistics regarding deficiencies during operation in the storage sites may further help in establishing an effective emergency fire fighting plan, and its implementation may reduce the number of fire incidents in future.

Regarding fire incidents, 2009 was the worst year during the studied period, with losses of $10.8 \mathrm{M}$ SEK. Inclusion of social and environmental costs may raise the figures of economic losses. The economic circumstances must be changed in such a way that it will never be economically beneficial for a company to have a fire. In the case of a company taking high risks, it should also pay fully for even the social and environmental costs.

\section{ACKNOWLEDGMENTS}


The authors acknowledge the Higher Education Commission of Pakistan for providing funds for Mr Ibrahim's studies and also the environmental managers at all the companies that gave very positive feedback to the project.

\section{REFERENCES}

[1].Wiqvist, W., (2009) "Svensk avfallshantering", (Swedish waste management), Avfall Sverige, $35 \mathrm{pp}$.

[2].Hogland, W., Bramryd, T. and Persson, I., (1996) "Physical, biological and chemical effects of unsorted fractions of industrial solid waste in waste fuel storage", Waste Management \& Research, 14, 197-210

[3].Hogland, W. and Marques, M., (2003) "Physical, biological, chemical processes during storage and spontaneous combustion of waste fuel". Resources, Conservation and Recycling, 40 (1), 53-69.

[4]. Lönnermark, A., Persson, H., Blomqvist, P. and Hogland, W., (2008b) “'Biobränslen och avfall - Brandsäkerhet i samband med lagring', (Biofuels and wastes - Fire safety in the storage), SP Sveriges Tekniska Forskningsinstitut, SP Rapport 2008:51 (in Swedish).

[5].Persson, B. and Simonson, M., (1998) "Fire emissions into atmosphere", Fire Technology, 34 (3), 266-279.

[6].RVF, (2003) "Bränder i avfall vid deponier och förbränningsanläggningar", (Fires in the waste at landfills and incinerators), RVF rapport 2003:11. Svenska Renhållnigsverksföreningen, Malmö, Sweden (in Swedish).

[7].Blomqvist, P., Persson, B. and Simonson, M., (2007) "Fire emissions of organics into the atmosphere", Fire Technology, 43, 213-231.

[8].Passant, N. R., (1993) "Emissions of volatile organic compounds from stationary sources in the UK", Warren Spring Laboratory, Report No. LR990.

[9].Lee, D. S. and Atkins, D. H. F., (1994) "Atmospheric ammonia emissions from agricultural waste combustion", Geophysical Research Letters, 21 (4), 281-284.

[10].Bergström, J. and Björner, B., (1994) “Bränder på avfallsupplag”, (Fires at landfill sites), Naturvårdsverket rapport 4320 (in Swedish).

[11].Lemieux, P. M., (1998) "Evaluation of emissions from the open burning of household waste in barrels", Environmental Protection Agency, EPA/600/SR-97/134.

[12].Nammari, D. R., Hogland, W. and Marques, M., (2004) "Emissions from a controlled fire in municipal solid waste bales", Waste Management, 24, 9-18.

[13].Sandstedt, K. and Nammari, D. (2006) "Fire at a waste storage, Aalborg Denmark", Department of Technology, 2006.

[14].Hogland, W., Lönnermark, A., Marques, M. and Persson, H., (2009) "Storage of Organic Materials, Solid Waste and Biofuels - Risks for fires and fire fighting". Proceedings Sardian 2009, Twelfth International Waste Management and Landfill Symposium, S. Margherita di Pula, Cagliari, Italy, 5-9 October 2009, 10 pp.

[15].Lönnermark, A., Blomqvist, P. and Marklund, S., (2008a), "Emissions from simulated deep-seated fires in domestic waste", Chemosphere, 70, 626-639.

[16].Dillman, D., (2000). "Mail and Internet surveys: The tailored design method" (2nd ed.). New York: Wiley.

[17].Tuten, T. L., (1997) "Electronic methods of collecting survey data: A review of eresearch", Zentrum für Umfragen, Methoden und Analysen (ZUMA), ZUMAArbeitsbericht Nr. 97/09, Mannheim, Germany.

[18].Dillman, D., Eltinge, J., Groves, R. and Little, R., (2002) "Survey Nonresponse in Design, Data Collection, and Analysis", Chapter 1 in Groves, R.; Dillman, D., Eltinge, J. and Little, R. (eds.), Survey Nonresponse, New York: John Wiley and Sons, 3-26 pp. 
[19].Beuckelaer, A. D. and Lievens, F., (2009) "Measurement equivalence of paper-andpencil and internet organisational surveys: A large scale examination in 16 countries", Applied Psychology, 58 (2), 336-361.

[20].Lautenschlager, G. J. and Flaherty, V. L., (1990) "Computer administration of questions: More desirable or more social desirability?", Journal of Applied Psychology, 75, 310-314.

[21].Booth-Kewley, S., Edwards, J. E. and Rosenfeld, P., (1992) "Impression management, social desirability, and computer administration of attitude questionnaires: Does this make a difference?", Journal of Applied Psychology, 77, 562-566.

[22].Schonland, A. and Williams, P., (1996) "Using the internet for travel and tourism survey research: Experiences from the net traveler survey", Journal of Travel Research, 35 (2), $81-87$.

[23].Björklund, C., Byman, K. and Toll, M., (2001) "Olyckors utsläpp och deras miljöpåverkan i relation till de nationella miljömålen", Räddningsverket, Karlstad, ISBN 91-7253-113-4 (in Swedish).

[24].NAS, (2006) "Health risks from dioxin and related compounds- Evaluation of the EPA reassessment", Washington DC, the national academies press.

[25].De Wit, C., (1995) Swedish Dioxin Survey. Preliminary data. Solna, Sweden.

[26].UNEP, (1999) "Dioxin and furan inventories; national and regional emissions of PCDD/PCDF”, UNEP chemicals, Geneva, Switzerland, 102 pp.

[27].Quaß, U., Fermann, M. and Bröker, G., (2004) "The European dioxin air emission inventory project-final results", Chemosphere, 54, 1319-1327.

[28].Quaß, U., Fermann, M. and Bröker, G., (2000) "Steps toward a European dioxin emission inventory", Chemosphere, 40, 1125-1129.

[29].Sundqvist, J. O., (1999) "Life cycle assessment and solid waste - Guidelines for solid waste treatment and disposal in LCA", AFR-report 279, IVL, Swedish Environmental Research Institute, $133 \mathrm{pp}$.

[30].Woodfield, M., (2006) "Emission inventory guide book", European Environmental Agency, Technical Report 11/2006.

[31].Petersson, K., Boström, C. Å. and Antonsson, A.-B., (1996) "Bränder på avfallsupplagmätningar av luftföroreningar i arbetsmiljön och emissioner till den yttre miljön i samband med släckning av tippbränder", IVL Institutet för vatten- och luftvårdsforskning, Stockholm, IVL rapport B 1211 (in Swedish).

[32].Ettala, M., Rahkonen, P., Rossi, E., Mangs, J. and Keski-Rahkonen, O., (1996) "Landfill fires in Finland", Waste Management \& Research, 14, 377-384. 